\title{
The Effect of Health Education with PHBS Media on the Knowledge Level of Santri Pondok Zam-Zam Islamic Boarding School, Cilongok
}

\author{
Krisna Maulidian ${ }^{1}$, Kris Linggardini ${ }^{2}$ \\ ${ }^{1,2}$ Department of Health, Universitas Muhammadiyah Purwokerto, Indonesia
}

\begin{abstract}
Clean and healthy living behavior (PHBS) is one way to maintain health to avoid various diseases caused by bacteria and viruses. The boarding school environment that applies dormitory education makes the spread of diseases often occur such as scabies (skin disease), scabies, diarrhea, ARI. Knowledge of PHBS coupled with behavior is very important to avoid the disease. The dissemination of knowledge using video is more attractive to students so that the enthusiasm to learn about the importance of PHBS will be conveyed.To determine the effect of health education with the video media on Clean and Healthy Behavior (PHBS) on the knowledge level of students at the ZamZam Islamic Boarding School Cilongok.This study uses quantitative research, with a pre-experimental design and a one- group pretest-posttest approach without control design. The sample used in this study were 60 respondents, the sampling technique was cluster sampling. The results showed that the knowledge score before intervention with an average of 18.76 with a standard deviation of 2.94 increased to 25.96 with a standard deviation of 0.86 . The results of bivariate analysis using the Wilcoxon test, obtained a $\mathrm{Z}$ value of -6749 and a significance value of $0.0001(\mathrm{p}<0.05$ ). There is an effect of health education with the media of Clean and Healthy Behavior (PHBS) video on the knowledge level of students at the Zam-Zam Islamic Boarding School Cilongok
\end{abstract}

This work is licensed under a Creative Commons Attribution 4.0 International License.

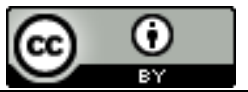

Corresponding Author:

Kris Linggardini,

Department of Health, Universitas Muhammadiyah Purwokerto,

Soepardjo Rustam Street KM. 7, Banyumas, Indonesia

Email: linggardini75@gmail.com

\section{INTRODUCTION}

The World Health Organization (WHO) states that every year 2.2 million people in developing countries, especially children, die from diseases caused by poor Clean and Healthy Behavior (PHBS) and lack of safe drinking water for consumption. . The mortality rate can be suppressed with adequate sanitation services, adequate sanitation supplies, adequate supplies, and adequate waste disposal systems as much as $65 \%$ due to diarrhea and $26 \%$ due to other diseases [1].

Indonesian Ministry of Health, (2017). Stated as many as 10,294 cases of health problems including maternal and child mortality $(\mathrm{MCH})$ as a result of poor diet and Clean and Healthy Lifestyle (PHBS). Another cause is the lack of attention to environmental health problems. Household waste that is disposed of carelessly without any process selection and recycling is the cause of the disruption of the natural balance that has an impact on the emergence of various diseases. Then the facts on the ground reveal that as many as $68 \%$ of Indonesian people are still far from PHBS indicators. One example of the consequences of these bad habits is the increasing number of people with infectious diseases such as scabies (skin disease), scabies, diarrhea, ARI. This is also often experienced by students in Islamic boarding schools. Due to conditions that strongly support the spread of disease due to an unhealthy lifestyle that is applied in the environment. [2]. 
Clean and Healthy Living Behavior (PHBS) is a series of behaviors based on awareness which is the result of learning, which allows individuals or families to help themselves in the health sector and play an active role in realizing public health. Indicators of the order of clean and healthy behavior consist of behavioral indicators and environmental indicators in six settings, namely household arrangements, workplace arrangements, public places arrangements, school settings, 2 health facilities arrangements and Islamic boarding schools [3].

The indicators used as a measure to assess PHBS at the education level are washing hands with running water, and using soap, consuming snacks at the boarding school canteen, using clean and healthy latrines, exercising regularly and measurably, eradicating mosquito larvae, not smoking, weighing body and measure height every 6 months and dispose of garbage in its place [4].

Pondok Pesantren is a center of learning and da'wah. As the oldest educational institution in Indonesia, pesantren plays a very important role in the history of education. however, in carrying out the management of Islamic boarding schools, there are still other factors that become prominent characteristics among the pesantren community, especially in the past. The problem is the cleanliness of the Islamic boarding school environment which is known to be dirty, slum and unhygienic [5].

According to [6 ] the factors that cause the low quality of students' health behavior are regulations, facilities, and close friends at the cottage. Sanitation conditions in Islamic boarding schools will be closely related to infectious environmental-based morbidity rates. Several sanitation problems are very common in Islamic boarding schools, including limited sanitation facilities and the behavior of students who have not practiced PHBS. This can be seen in the results of a survey conducted at the UPTD Puskesmas Paiton Probolinggo, namely in 2011 to 2012, there were 36 students suffering from dermatitis, 70 students suffer from GEA, 40 students suffer from allergies, 498 students suffer from scabies, 59 students suffer from gastritis, 100 students suffer from typhoid, 87 students suffer from ARI, and 230 students suffer from fever.

Through an initial study or pre-survey at the Zam-Zam Muhammadiyah Islamic Boarding School, Cilongok using the interview method conducted to 10 students, it can be seen that the level of knowledge of students about PHBS in Islamic boarding schools is very low. Based on the results of the pre-survey, 7 (70\%) respondents did not know what PHBS stands for and out of 10 (100\%) respondents did not know the number of PHBS indicators in schools. The result of direct observation in the field is that many students do not apply the habit of washing their hands in running water before eating. Do not immediately wash cutlery in the form of plates and spoons after eating, littering is still careless, changing patterns of clothes are not regular, room cleanliness is still lacking, and the lack of health information media such as posters and leaflets as a means of health education and the lack of counseling about hygiene at the boarding schooll.

The use of media in health education counseling directly and through mass media must consider the age and interests of the participants. Early adolescence is the right age to get counseling using the media. Media that can be used for health education can use power point media, flipcharts, audiovisual media, newspapers, magazines, TV, radio and other media. (Haryani, S. 2016). The use of video as a means of health education is now starting to be developed along with current technological advances. Health counseling through video media has advantages in terms of providing good visualization so as to facilitate the process of absorbing knowledge. Video is included in audio-visual media because it involves the sense of hearing as well as the sense of sight. This audio-visual media is able to produce better learning outcomes for tasks such as remembering, recognizing, recalling and connecting facts and concepts [7].

Based on research by [8], the results of statistical tests using non-parametric Wilcoxon test p-value $=$ 0.001 on 14 respondents, there is an effect before and after health education through video media, meaning that before and after health education through video media there was a significant effect on the level of knowledge of school health service cadres about clean and healthy behavior. Health education through video media is an effective means to increase understanding of hygiene and healthy living habits among school students.

Based on the explanation above, the researcher considers that it is necessary to do in-depth and comprehensive research in a study entitled "The effect of health education with PHBS video media on the level of knowledge of students at the Zam-Zam Islamic Boarding School Cilongok.

\section{RESEARCH METHOD}

This study uses a quantitative descriptive method with a pre-experimental design with a one-group pretest-posttest approach without control design. The sampling technique used cluster random sampling with a sample of 60 respondents who matched the inclusion and exclusion criteria. The distribution of the questionnaires in this study was direct with a time of 1 week. 


\section{RESULT AND DISCUSSIONS}

\subsection{Univariat}

Table 4.1 Table of scores for the distribution of knowledge values of students about health education using the video media for Clean and Healthy Lifestyle.

\begin{tabular}{lcr}
\hline \multicolumn{1}{c}{ Category } & Before & After \\
\hline Well & 20 & 60 \\
Enough & 34 & 0 \\
Less & 6 & 0 \\
\hline Amount & 60 & 60 \\
\hline
\end{tabular}

Based on table 4.1, it is known that the respondents had a knowledge score before the intervention in the dominance of moderately knowledgeable students with a total of 34 students, then after the intervention underwent a change, all students had good knowledge.

Table 4.2 Knowledge scores before and after health education interventions using the video media for Clean and Healthy Behavior)

\begin{tabular}{lrr}
\hline \multirow{2}{*}{ Average } & Before intervention \% & \multicolumn{2}{c}{ After intervention \% } \\
\cline { 2 - 3 } median & 69,48 & 96.14 \\
Standard deviation & 70.37 & 96.29 \\
Minimum & 10.88 & 3.18 \\
Maximum & 40.74 & 88,88 \\
& 88.89 & 100 \\
\hline
\end{tabular}

Based on table 4.2, it is known that respondents have a knowledge score before the intervention with an average of $69.48 \%$ with a standard deviation of $10.88 \%$ then after the intervention has changed to an average value of $97.14 \%$ and a standard deviation to $3.18 \%$.

\subsection{Bivariat}

Bivariate analysis in this study used data analysis with the Wilcoxon test. The statistical test used to determine the effect of health education with the media of Clean and Healthy Behavior (PHBS) video on the knowledge level of the students of the Zam-Zam Islamic Boarding School Cilongok is the Wilcoxon $t$ $(\mathrm{N}=45)$.

Table 4.3 the effect of health education with the video media on Clean and Healthy Behavior (PHBS) on the knowledge level of students at the Zam-Zam Islamic boarding school Cilongok

\begin{tabular}{|c|c|c|c|c|c|c|}
\hline & $\mathrm{N}$ & $\begin{array}{c}\begin{array}{c}\text { Median } \\
\text { (min- } \\
\max \text { ) }\end{array}\end{array}$ & Average $\pm s b$ & $\begin{array}{l}\text { mean } \\
\text { different }\end{array}$ & $\begin{array}{c}\mathrm{Z} \\
\text { value }\end{array}$ & $\begin{array}{c}p \\
\text { value }\end{array}$ \\
\hline $\begin{array}{l}\text { Prior } \\
\text { knowledge } \\
\text { score }\end{array}$ & 60 & $\begin{array}{c}24 \text { (16- } \\
27)\end{array}$ & $18.7667 \pm 2.94219$ & & & \\
\hline $\begin{array}{l}\text { Enduring } \\
\text { score } \\
\text { After }\end{array}$ & 60 & $\begin{array}{c}26(24- \\
27)\end{array}$ & $25.9667 \pm 0.86292$ & 7.2 & - & 0.0001 \\
\hline
\end{tabular}

Based on the results of the study above, the average value of knowledge of respondents before the intervention was $18.7667 \pm 2.94219$ and after the intervention the average value of knowledge increased to 
$25.9667 \pm 0.86292$ or increased by 2.2 times. The results of bivariate analysis using the Wilcoxon test, obtained a $\mathrm{Z}$ value of -6749 and a significance value of $0.0001(\mathrm{p}<0.05)$.

The results of this statistical test can be concluded that there is an effect of health education with the media of Clean and Healthy Behavior (PHBS) video on the knowledge level of the students of the Zam-Zam Islamic Boarding School Cilongok with a $\mathrm{P}$ value of 0.0001 .

\subsection{Knowledge Score Before health education intervention with video media Clean and Healthy Behavior}

The results showed that the respondents had a knowledge score before the intervention with an average of 18.7667 with a standard deviation of 2.94219 . Knowledge can be obtained by observing, observing, and personal experience. Knowledge is influenced by the number of sources of information obtained, the more information obtained about clean and healthy living, the knowledge of clean and healthy living will be better [9]. The reason for holding health education using videos to develop handwashing behavior among students is to develop knowledge so that students' knowledge gets better.

The results of the questionnaire answers show that there are three questions with the lowest score, namely the understanding of PHBS, food that is not good for consumption and how to maintain nail hygiene. The number of students who do not know what PHBS stands for, good food and nail hygiene is due to a lack of information in the lodge. In addition, the provision of food from the cottage makes the students do not need to choose or buy food from outside so that it is guaranteed. The lack of nail hygiene especially when eating makes the boarding school students vulnerable to digestive tract diseases.

Clean and healthy living behavior (PHBS) is one way to achieve good health. The success of health development is also determined by the continuity between program and sector efforts, as well as continuity with the efforts that have been implemented in the previous period [10].

The implementation of poskestren in Islamic boarding schools is less than optimal in implementing the poskestren program to improve the health status of pesantren residents including the application of a clean and healthy lifestyle, this is due to the lack of awareness of the application of the clean and healthy living behavior. So far, health promotion, both promotive, preventive, curative and rehabilitative has only been carried out by the UKS pesantren. All students, educators. The supervisor and the community in the Islamic boarding school environment must improve the implementation of PHBS. This has not been implemented optimally in Islamic boarding schools so that health empowerment in the Islamic boarding school environment has not been carried out thoroughly, the impact is that there are still health problems caused by a lack of clean and healthy living behavior.

\subsection{Knowledge Score After health education intervention with video media Clean and Healthy Behavior}

The results showed that the respondents had a knowledge score after the intervention with an average of 25.9667 with a standard deviation of 0.86292 . Knowledge is the result of human sensing or the result of someone knowing about objects through the senses (eyes, nose, ears, and so on). Knowledge basically consists of a number of facts and theories that allow a person to be able to solve the problems he faces. This knowledge is obtained both from direct experience and the experiences of others [11].

The increasing knowledge score of students shows that the quality of the video is very feasible to use because students need health information and education so that the scores obtained are in the range of $90 \%-100 \%$, so the media is very feasible to use [12]. Counseling on clean and healthy living behavior (PHBS) is an attempt to convey health messages to the community, groups, or individuals, with the hope that the public can gain knowledge about better health and influence their behavior [13].

According to [14], that there are three domains that can be changed by a person through health education, namely knowledge, skills and attitudes. Health education creates opportunities for individuals to continuously improve awareness ( literacy), as well as increase knowledge and skills (life skills) in order to achieve optimal health [15]. According to Notoatmojo (2010) said that a good learning process will get good results as well. Knowledge is one of the factors that can influence individual attitudes and behavior.

The results of the questionnaire calculation showed that all questions had a significant increase in score after 2 days of health education. This proves the effectiveness of the videos made by researchers in influencing the knowledge of respondents.

\subsection{The effect of health education with the video media on Clean and Healthy Behavior (PHBS) on the knowledge level of students at the Zam-Zam Islamic Boarding School Cilongok}

The results of the study showed that there was an effect of health education with the media of Clean and Healthy Behavior (PHBS) video on the knowledge level of the students of the Cilongok Zam-Zam 
Islamic Boarding School. Knowledge is everything that is known, everything that is known regarding the subject matter. Knowledge is something that is uniquely human because it comes from humans and for humans for the sake of their humanitarian duties. It can be said that knowledge is not nature (given), but a human creation that integrates inner sensitivity, intellectual sharpness (rationality) and social sensitivity to values and social situations [16].

The results of this study are in line with [17], which proves that there is an effect of providing PHBS counseling about hand washing with soap on the knowledge of hand washing with soap in fifth grade students at SDN Taman Kota Serang. Then according to [18], there is an effect of health education with the video playback method on students' knowledge and attitudes about PHBS washing hands.

Knowledge can be influenced by the provision of video media because video can reflect a more effective absorption of information by using the senses of sight and hearing and can increase knowledge compared to only using the sense of sight [19]. Mother's knowledge improvement. This type of media has better abilities, because it includes both types of auditory (hearing) and visual (seeing) media which means materials or tools used in learning situations to assist written and spoken words in transmitting knowledge, attitudes, and ideas [20].

Audio-visual media such as video are effective for increasing students' knowledge because audiovisual media stimulates the sense of hearing and the sense of sight in obtaining information about cardiopulmonary resuscitation. Audio-visual media contributes greatly to the information and persuasion aspects of behavior change [21]. This is because audio-visual media can stimulate the sense of hearing and the sense of sight by approximately $75-87 \%$ in channeling information to the brain. Based on the pyramid of Edgar Dale's experience with audio-visual media, it is also stated that $50 \%$ of a person learns from what he sees and hears [22].

In line with [23], that the level of media used in learning can form real experiences on learning targets. Some of the influencing factors include media, print reading media (eg posters) whose concrete level is lower than audio-visual (eg video or television), audio-visual media whose concrete level is lower than guided practicum (direct practice) and so on.

The success of video in improving learning outcomes cannot be separated from the advantages of video. The advantages of video are that it can provide a message that can be received more evenly, overcomes the limitations of space and time, is more realistic, can be repeated and stopped as needed, gives a deep impression, which can affect attitudes, is very good for explaining a process (Susilana \& Riyana, 2009), flexible in sharing information, participants can get information anywhere as long as there is a video player, easy to duplicate, \& good for motivating [24].

The use of media in health education has the aim of attracting attention to a problem and reminding the information conveyed in order to cause changes in knowledge and attitudes and behavior (Muhsaini, et al., 2011). This is in accordance with the effect of providing audio visual video media counseling . Behavior that is based on knowledge will be more lasting than behavior that is not based on knowledge. If the acceptance of a new behavior or the adoption of a behavior is based on knowledge, understanding, awareness, and a positive attitude, then the behavior will be long-lasting. Conversely, if behavior is not based on knowledge, understanding and awareness, it will not last long. For example, students are encouraged to clean nails by their teachers without knowing the meaning and purpose of cleaning nails, so most of the children will underestimate these activities even though they have received an appeal [25].

Health education emphasizes efforts to change or improve knowledge that stimulates students to behave in a healthy manner. In PHBS, students are expected to be able to recognize clean and healthy living behavior, which is marked by 18 indicators of implementing PHBS in the setting of Islamic boarding schools. Managers of Islamic boarding schools can follow to identify clean and healthy living, then recognize the condition of the environment and measure the level of environmental health. [25]

Another study conducted by Ampofo (2020), which examined " A pilot study of a video-based educational intervention and knowledge of cervical cancer among senior high school students in Ghana: A before-after study". Shows a significant relationship with the addition of knowledge and awareness of the causes of cervical cancer with a $p$ value of 0.003 . In this study, counseling with video media that is displayed using laptop media with a liquid crystal display (LCD) is a stimulus or object that is expected to have an influence on respondents to behave in accordance with the message or content of the information conveyed.

\section{CONCLUSION}

Based on the results and discussion in the thesis about "the effect of health education with the video media of Healthy Clean Living Behavior (PHBS) on the knowledge level of students at the Zam-Zam Cilongok Islamic boarding school", it can be concluded as follows: 
1. The average knowledge score before intervention was 18.7667 with a standard deviation of 2.94219

2. The average knowledge score after the intervention was 25.9667 with a standard deviation of 0.86292

3. There is an effect of health education with the video media of Clean and Healthy Lifestyle (PHBS) on the knowledge level of the students of the Zam-Zam Islamic Boarding School Cilongok with a P value of 0.0001 .

Acknowledgements

Thank you to Allah SWT, both parents and all comrades in arms who have helped from beginning to end.

\section{REFERENCES}

[1] Abdullah, Ishak dkk, "Teknologi Pendidikan," Bandung: PT Remaja Rosdakarya, 2013.

[2] Adiwiryono, R. M., "Pesan Kesehatan: Perilaku Hidup Bersih dan Sehat (PHBS) Anak Usia Dini dalam Kurikulum Pendidikan Anak Usia Dini," Jurnal Ilmu Kesehatan Universitas Muhammadiyah Prof. Hamka, 52, 2010.

[3] Anik Maryunani, "Perilaku Hidup Bersih dan Sehat," Jakarta: Trans Info Media, 2013.

[4] Astuti, Yulia., dkk., "Perilaku Hidup Bersi dan Sehat. Modul Field Lab Semester V," Universitas Sebelas Maret, 2013.

[5] Atikah Proverawati, Eni Rahmawati, "Perilaku hidup bersih dan sehat (PHBS)," Yogyakarta: Nuha Medika, 2012.

[6] Dachroni, "Kajian PHBS Ditinjau Dari Sudut Pandang Agama Islam [online]," 2013, Tersedia di: http://dinkesjatengprov.go.id/v 2015/index.php/39- rokcontent/frontpage/173- kajian-perilakudup-bersih- dan-sehat-phbs- ditinjau-dari- sudut-pandang-agama-islam. (diunduh pada tanggal 29 Maret 2016, jam 15.00 WIB

[7] Departemen Kesehatan Republik Indonesia, "Rumah Tangga Berperilaku Hidup Bersih dan Sehat," Jakarta: Depkes RI, 2008.

[8] Departemen Kesehatan RI, "Undang- Undang Republik Indonesia Nomor 36 Tahun 2009 Tentang Kesehatan," Jakarta: Kementrian Kesehatan RI, 2009.

[9] Departemen Kesehatan Republik Indonesia, "Rumah Tangga Berperilaku Hidup Bersih dan Sehat," Jakarta: Depkes RI, 2008.

[10] Dinkes Jawa Tengah, "Profil Kesehatan Provinsi Jawa Tengah Tahun 2015," Semarang: Dinkes Jawa Tengah, 2015.

[11] Hamdani, "Strategi Belajar Mengajar," Bandung: Pustaka Setia, 2011.

[12] Hidayat, Aziz Alimul. "Metode penelitian keperwatan dan teknik analisa data," Jakarta : Salemba Medika, 2007.

[13] Kemenkes RI., "Profil Kesehatan Indonesia 2016," Keputusan Menteri kesehatan Republik Indonesia. Jakarta, 2017.

[14] Kementerian Kesehatan Republik Indonesia, "Profil Kesehatan Indonesia," Jakarta: Kementerian Kesehatan Republik Indonesia, 2014.

[15] Kementrian Kesehatan RI., "Pedoman Pembinaan Perilaku Hidup Bersih dan Sehat," Jakarta: Kementrian Kesehatan, 2011

[16] Kementrian Kesehatan RI., "Profil Kesehatan Indonesia 2014," Kementrian Kesehatan RI. Jakarta, 2015.

[17] Mubarak dkk., "Promosi Kesehatan: Sebuah Pengantar Proses Belajar Mengajar dalam Pendidikan," Yogyakarta: Graha Ilmu, 2007.

[18] Mulyadi, M. I., Warjiman, W., \& Chrisnawati, C., "Efektifitas Pendidikan Kesehatan dengan Media Video terhadap Tingkat Pengetahuan Perilaku Hidup Bersih dan Sehat," Jurnal Keperawatan Suaka Insan (JKSI), Vol.3, No.2, 2018.

[19] Notoatmodjo Soekidjo, "Ilmu Perilaku Kesehatan," Jakarta: Rineka Cipta, 2010.

[20] Notoatmodjo, S., "Ilmu Perilaku Kesehatan," Jakarta: Rineka Cipta, 2014.

[21] Notoatmodjo, Soekidjo., "Pendidikan dan perilaku kesehatan," Jakarta: Rineka Cipta, 2012.

[22] Notoatmodjo., "Metodologi penelitian kesehatan," Jakarta: Rineka Cipta, 2010.

[25] Nursalam, N., \& Efendi, F, "Pendidikan Dalam Keperawatan Education in Nursing," 2008. 
[24] Promkes Kemenkes, R. I., "Program Hidup Bersih dan Sehat di Rumah," Jakarta: Kemenkes RI, 2016.

[25] Proverawati, A., dkk., "PHBS Perilaku Hidup Bersih dan Sehat," Yogyakarta: Nuha Medika, 2012. 